\title{
Protocol
}

\section{Purification of Rat and Mouse Astrocytes by Immunopanning}

\author{
Lynette C. Foo ${ }^{1}$ \\ Stanford University, School of Medicine, Department of Neurobiology, Stanford, California 94305
}

\begin{abstract}
We describe the use of immunopanning to purify rodent astrocytes. Immunopanning of astrocytes permits the prospective isolation of astrocytes from the rodent brain. Prospective isolation refers to the direct selection of cells without multiple steps that extend over a few days, thereby permitting the selection of a representative proportion of the astrocytes from the cortex. Because immunopanning is a very gentle process, the cells are viable at the end of the preparation and can be cultured in a serum-free medium containing heparin-binding EGF-like growth factor (HBEGF), the critical survival factor of astrocytes in vitro, for at least $2 \mathrm{wk}$. This protocol was initially established and verified with rats, but modifications for the purification of mouse cells are also described here.
\end{abstract}

\section{MATERIALS}

It is essential that you consult the appropriate Material Safety Data Sheets and your institution's Environmental Health and Safety Office for proper handling of equipment and hazardous materials used in this protocol.

RECIPES: Please see the end of this article for recipes indicated by $<R>$. Additional recipes can be found online at http://cshprotocols.cshlp.org/site/recipes.

Reagents

Animals (rats or mice) for dissection

Brain dissections are typically done on animals between P0 and P10 but can be done up to P15. Cell yield and viability decrease dramatically with age, because it is more difficult to dissociate older tissue with increased myelination in the brain and increased process elaboration of the astrocytes. Hence, there is more damage to the astrocytes with older animals.

BSA $(4 \%)$

To prepare a stock of $4 \%$ BSA in Dulbecco's phosphate-buffered saline (D-PBS), dissolve $8 \mathrm{~g}$ of $B S A$ (Sigma-Aldrich A4161) in $150 \mathrm{~mL}$ of D-PBS (HyClone SH30264.01) at $37^{\circ} \mathrm{C}$. Adjust the $\mathrm{pH}$ to 7.4 with $\sim 1 \mathrm{~mL}$ of $1 \mathrm{~N} \mathrm{NaOH}$. Bring the volume to $200 \mathrm{~mL}$. Filter through a $0.22-\mu \mathrm{m}$ filter. Store in 1-mL aliquots at $-20^{\circ} \mathrm{C}$.

BSL-1 (Griffonia simplicifolia lectin; Vector Labs L-1100; $5 \mathrm{mg} / \mathrm{mL}$ )

DNase (0.4\%)

To prepare a $0.4 \%$ stock of DNase in Earle's balanced salt solution (EBSS), add $1 \mathrm{~mL}$ of EBSS (SigmaAldrich E6267) per 12,500 units of DNase (Worthington LS002007 or Sigma-Aldrich D4527). Keep on ice. Filter-sterilize, and store in $200-\mu \mathrm{L}$ aliquots at $-20^{\circ} \mathrm{C}$.

Dulbecco's phosphate-buffered saline (D-PBS) containing $\mathrm{Mg}^{2+}$ and $\mathrm{Ca}^{2+}$ (HyClone SH 30264.01)

Store at room temperature.

\footnotetext{
${ }^{1}$ Correspondence: lynettefoo@gmail.com

(C) 2013 Cold Spring Harbor Laboratory Press

Cite this article as Cold Spring Harb Protoc; 2013; doi:10.1101/pdb.prot074211
} 
L.C. Foo

Earle's balanced salt solution (EBSS without $\mathrm{Mg}^{2+}$ or $\mathrm{Ca}^{2+}, 1 \times$; Sigma-Aldrich E6267), equilibrated as in Step 2.ii

Store at room temperature until opened, and then store at $4^{\circ} \mathrm{C}$.

Enzyme stock solution $<\mathrm{R}>$

Fetal calf serum (FCS)

Dilute 100\% FCS (Gibco/Life Technologies 10437-028) in a 50/50 mixture of DMEM (Gibco/Life Technologies 11960-044) and Neurobasal (Gibco/Life Technologies 21103-049). The 100\% FCS should be heatinactivated for $30 \mathrm{~min}$ at $55^{\circ} \mathrm{C}$ and stored at $-20^{\circ} \mathrm{C}$. Dilute to $30 \%$ before use.

High ovomucoid stock solution $(10 \times)<\mathrm{R}>$

Inhibitor stock solution $<\mathrm{R}>$

L-cysteine hydrochloride monohydrate (Sigma-Aldrich C7880)

Low ovomucoid stock solution $(10 \times)<\mathrm{R}>$

Media (equilibrate as in Step 2.ii before use):

- IP-astrocyte base medium $<\mathrm{R}>$

- IP-astrocyte base medium containing 5 ng/mL HBEGF (Sigma-Aldrich E4643)

Papain (Worthington LS003126)

Primary antibodies:

- Mouse anti-human integrin $\beta 5$ (ITGB5), affinity purified (eBioscience 14-0497-82)

- O4 hybridoma supernatant mouse IgM (Bansal et al. 1989)

- Rat anti-mouse CD45 (BD Biosciences Pharmingen 550539)

The antibodies listed here are for use with the rat immunopanning protocol. See the end of the Method section for the antibodies needed for mouse immunopanning.

Secondary antibodies:

- Goat anti-mouse IgG + IgM (H + L) (Jackson ImmunoResearch 115-005-044)

- Goat anti-mouse IgM $\mu$-chain specific (Jackson ImmunoResearch 115-005-020)

- Goat anti-rat IgG (H + L) (Jackson ImmunoResearch 112-005-167)

The antibodies listed here are for use with the rat immunopanning protocol. See the end of the Method section for the antibodies needed for mouse immunopanning.

Tris-HCl (50 mm, pH 9.5), sterilized

Trypan blue

Trypsin (30,000 units/mL) (Sigma-Aldrich T9935)

Do not store aliquoted trypsin at temperatures warmer than $-80^{\circ} \mathrm{C}$. Warmer temperatures allow a low level of trypsin activity, enabling the enzyme to cleave itself and render itself inactive.

Equipment

ACLAR plastic coverslips, ethanol-washed and PDL-coated

In practice, we coat ethanol-washed ACLAR coverslips with poly-D-lysine (PDL) after adding them individually to each well of a 24-well plate (see Step 56). ACLAR is very hydrophobic; add $500 \mu L$ of $0.01 \mathrm{mg} / \mathrm{mL}$ PDL (prepared in sterile $\mathrm{H}_{2}$ O) to cover each coverslip completely. If the coverslip floats up, tap it down with a pipette tip. Coat the coverslips with PDL for at least $30 \mathrm{~min}$. Wash the coverslips in the wells three times with sterile $\mathrm{H}_{2} \mathrm{O}$ before adding medium.

Aspirator

Conical tubes $(50 \mathrm{~mL})$

Dissection equipment:

- Decapitation scissors, large (ROBOZ RS-6820)

- Dissecting microscope 
- Dissection scissors, curved (ROBOZ RS-5675)

- Forceps, \#5

- Forceps, curved

- Scalpel with No.10 scalpel blade

- Scissors, medium-sized (ROBOZ RS-6702)

- Scoop, perforated (Moria MC17)

Equilibration setup (a source of carbon dioxide $\left[5 \% \mathrm{CO}_{2} / 95 \% \mathrm{O}_{2}\right]$ with a line leading to a sterile hood)

Heat block preset to $34^{\circ} \mathrm{C}$ in a sterile hood

Hemacytometer

Incubator at $37^{\circ} \mathrm{C}, 10 \% \mathrm{CO}_{2}$

Microscope, phase contrast

Nitex mesh filter (Tetko HC3-20)

Cut into 3-inch squares, wrap in small packets of foil, and autoclave.

Petri dishes $(6 \mathrm{~cm}, 15 \mathrm{~cm})$

Petri dish lids $(6 \mathrm{~cm})$ with a hole in the center that accommodates a $0.22-\mu \mathrm{m}$ filter

Use flamed forceps (spray with ethanol and use a Bunsen flame to sterilize) to melt the hole into the center of the lid.

Pipette (1-mL)

Pipettes, serological (2-mL, 5-mL, 10-mL)

Pipettor, powered (e.g., Pipet-Aid)

Refrigerator preset to $4^{\circ} \mathrm{C}$

Sterile hood for tissue culture

Syringe, $20 \mathrm{~mL}$

Syringe filters $(0.22 \mu \mathrm{m})$

Tabletop centrifuge (with $15 \mathrm{~mL} / 50 \mathrm{~mL}$ centrifuge tube adaptors) at room temperature

Tissue culture plates $(15-\mathrm{cm})$

Tissue culture plates, multiwell (24-well)

Water bath at $34^{\circ} \mathrm{C}$

This method describes the purification of rat astrocytes (see Fig. 1 for an overview). It is a 2-d procedure; Step 1 is performed on the first day. Modifications required for purification of mouse astrocytes are outlined at the end.

Preparation of Panning Dishes

1. In a sterile hood, prepare the following panning dishes by coating six 15-cm Petri dishes with $25 \mathrm{~mL}$ of $50 \mathrm{~mm}$ Tris- $\mathrm{HCl}$ ( $\mathrm{pH} 9.5)$ per dish and the appropriate secondary antibody solution:

- One "Secondary antibody only" dish: $60 \mu \mathrm{L}$ goat anti-mouse IgG + IgM (H + L)

- One "BSL-1" dish: $40 \mu \mathrm{L} 50$ mm Tris-HCl (pH 9.5) + $20 \mu \mathrm{L}$ BSL-1

- One "CD45" dish: $60 \mu \mathrm{L}$ goat anti-rat IgG $(\mathrm{H}+\mathrm{L})$

- Two "O4" dishes: $60 \mu \mathrm{L}$ goat anti-mouse IgM $\mu$-chain specific

- One "ITGB5" dish: $60 \mu \mathrm{L}$ goat anti-mouse IgG + IgM (H + L) 
L.C. Foo

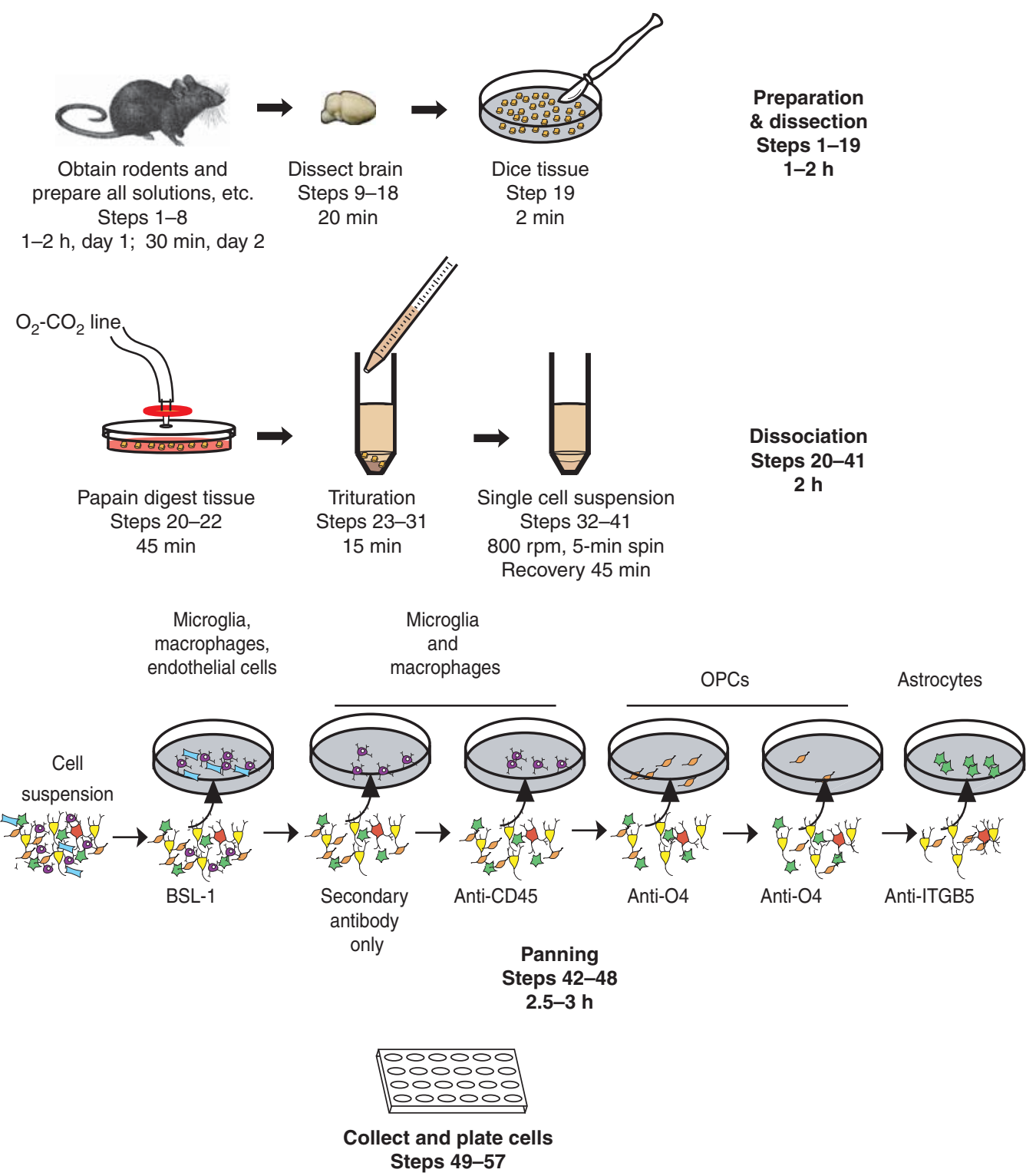

FIGURE 1. Immunopanning of astrocytes with anti-ITGB5.

Plates are initially hydrophobic, but after coating overnight, plates become visibly hydrophilic. If plates are needed immediately, a quick but less preferable way to make plates is to coat with secondary antibodies for $2 h$ at $37^{\circ} \mathrm{C}$.

Incubate the dishes with the antibody solutions overnight at $4^{\circ} \mathrm{C}$.

Preparation of Solutions and Panning Dishes

2. Aliquot and equilibrate the enzyme stock solution.

i. Aliquot $22 \mathrm{~mL}$ of enzyme stock solution into a $50-\mathrm{mL}$ conical tube.

ii. Break a $2-\mathrm{mL}$ pipette, attach a $0.22-\mu \mathrm{m}$ filter, and attach it to the $5 \% \mathrm{CO}_{2} / 95 \% \mathrm{O}_{2}$ line. Bubble $5 \% \mathrm{CO}_{2} / 95 \% \mathrm{O}_{2}$ through the solution until it turns from red to orange (see online Movie 1 at cshprotocols.cshlp.org).

iii. Put the tube of equilibrated enzyme stock solution into a $34^{\circ} \mathrm{C}$ water bath.

Astrocytes are exquisitely sensitive to $\mathrm{pH}$ changes. Yield and viability are highly affected by improper equilibration of the enzyme and dissociation media. All media in contact with cells must be properly equilibrated before use, including the growth medium that will be added. 
3. Aliquot and equilibrate the inhibitor stock solution.

i. Prepare two tubes with $21 \mathrm{~mL}$ per tube, and one tube with $10 \mathrm{~mL}$.

ii. Bubble $\mathrm{CO}_{2}$ through the solution until it turns from red to orange.

The 2-mL pipette from Step 2 can be re-used for this step. Do not put the equilibrated inhibitor stock into a water bath.

4. Prepare $60 \mathrm{~mL}$ of $0.2 \%$ BSA/DNase: Combine $57 \mathrm{~mL}$ of D-PBS with $3 \mathrm{~mL}$ of $4 \%$ BSA and $24 \mu \mathrm{L}$ of $0.4 \%$ DNase.

5. Prepare $50 \mathrm{~mL}$ of $0.02 \% \mathrm{BSA} / \mathrm{DNase}$ : Combine $45 \mathrm{~mL}$ of D-PBS with $5 \mathrm{~mL}$ of $0.2 \% \mathrm{BSA} / \mathrm{DNase}$ and $50 \mu \mathrm{L}$ of $0.4 \%$ DNase.

6. Prepare high and low ovo inhibitor solutions.

i. Combine the following for high ovo inhibitor solution: $10 \mathrm{~mL}$ of inhibitor stock solution + $2 \mathrm{~mL}$ of $10 \times$ high ovomucoid stock solution $+20 \mu \mathrm{L}$ of $0.4 \%$ DNase.

ii. Combine the following for low ovo inhibitor solution (prepare two conical tubes): $21 \mathrm{~mL}$ of inhibitor stock solution $+1.5 \mathrm{~mL}$ of $10 \times$ low ovomucoid stock solution $+100 \mu \mathrm{L}$ of $0.4 \%$ DNase.

7. Finish preparing the panning dishes from Step 1.

i. Wash each dish except for the BSL-1 dish three times with D-PBS.

ii. Coat with the appropriate primary antibody solutions:

- One "Secondary antibody only" dish: $12 \mathrm{~mL}$ of $0.2 \%$ BSA/DNase

- One "BSL-1" dish: None (leave unwashed and uncoated)

- One "CD45" dish: $20 \mu \mathrm{L}$ rat anti-mouse CD45 in $12 \mathrm{~mL}$ of $0.2 \%$ BSA/DNase

- Two "O4" dishes: $4 \mathrm{~mL}$ O4 hybridoma supernatant mouse IgM in $8 \mathrm{~mL}$ of $0.2 \% \mathrm{BSA} /$ DNase

- One "ITGB5" dish: $20 \mu \mathrm{L}$ of mouse anti-human ITGB5 in $12 \mathrm{~mL}$ of $0.2 \%$ BSA/DNase

Allow plates to incubate with primary antibody for at least $2 \mathrm{~h}$ at room temperature before use in Step 42.

8. Add 100 units of papain to the $22 \mathrm{~mL}$ of equilibrated enzyme stock solution from Step 2. Add $0.0036-0.0042 \mathrm{~g}$ of $\mathrm{L}$-cysteine. Warm the mixture in a $34^{\circ} \mathrm{C}$ water bath before beginning the dissection.

To maximize the activity of the enzyme, do not add it to the enzyme stock solution if it is not going to be used within 20 min. Preactivation of papain before usage optimizes the enzymatic activity, enabling shorter enzymatic dissociation times.

\section{Brain Dissection}

Dissect up to 8 P7 rat brains or 10 P7 mouse brains. Dissection should only take $\sim 20$ min (see online Movie 2 at cshprotocols.cshlp.org).

9. Prepare two 6-cm Petri dishes with $10 \mathrm{~mL}$ of D-PBS per dish.

10. Grab the animal to be dissected by the scruff and swiftly decapitate it with scissors. Discard the body.

11. Insert medium-sized scissors under the skin of the animal's head, avoiding the skull. Slide the scissors down the middle of the head to slice the skin into two halves. Gently pull apart the skin to reveal the skull.

12. Insert curved scissors into the base of the spinal cord, and make two cuts on each side. On one side, cut around the brain and horizontally across the part of the skull that covers the olfactory bulb.

13. Remove the skull flap, and cut the olfactory bulb with curved scissors. 
L.C. Foo

14. Gently insert curved forceps under the brain. Cut the optic nerve and transfer the brain into one of the D-PBS-containing Petri dishes from Step 9. As more animals are dissected, split the brains evenly between the two dishes.

15. Under a dissecting microscope, remove the midbrain, hindbrain, and striatal regions, leaving only the cortex.

16. Remove the meninges from the surface of the cortex by peeling them off with forceps.

This is easier to do with younger animals but can be done until $P 10$ on rats and $\sim P 7$ on mouse. Be careful not to make little tears in the surface of the cortex, so the meninges can be peeled off in sheets rather than in little sections.

17. Add a $200-\mu \mathrm{L}$ drop of D-PBS to the center of two 6-cm Petri dishes.

18. Use a perforated scoop to transfer the cortices to the drops of D-PBS. Split the cortices evenly between the dishes. Put a maximum of four rat cortices or five mouse cortices per Petri dish, to enable more thorough enzymatic dissociation.

19. Use a No. 10 scalpel blade to dice the brains into $\sim 1 \mathrm{~mm}^{3}$ pieces (see online Movie 3 at cshprotocols. cshlp.org).

Dissociation of the Cells

After papain treatment to loosen contacts in the extracellular matrix, the tissue is washed and then mechanically dissociated by gentle sequential trituration using a 5-mL pipette with fresh inhibitor solution to yield a suspension of single cells. This dissociation needs to be quick yet gentle to tease the cells apart rather than rip them apart; ripping will result in poor cell health.

20. In a sterile hood, attach a $0.22-\mu \mathrm{m}$ filter to a $20-\mathrm{mL}$ syringe. Filter and discard $2 \mathrm{~mL}$ of the enzyme stock solution prepared in Step 8. Then filter $10 \mathrm{~mL}$ of enzyme stock solution into each of the two Petri dishes containing finely diced brains (see online Movie 3 at cshprotocols.cshlp.org).

21. Add $50 \mu \mathrm{L}$ of $0.4 \%$ DNase to each Petri dish and swirl the dishes.

22. Allow the brains to digest by leaving the dishes for $40 \mathrm{~min}$ on a heat block set to $34^{\circ} \mathrm{C}$. Cover with lids that have holes in the top to accommodate a $0.22-\mu \mathrm{m}$ filter attached to the $5 \% \mathrm{CO}_{2} /$ 95\% $\mathrm{O}_{2}$ line. Bubble $\mathrm{CO}_{2}$ over the brains continuously and shake the dishes every 10-15 min (see online Movie 3 at cshprotocols.cshlp.org).

It is important to shake the dishes periodically!

23. Equilibrate $20 \mathrm{~mL}$ of $30 \% \mathrm{FCS}$ and $8 \mathrm{~mL}$ of EBSS in a $37^{\circ} \mathrm{C}, 10 \% \mathrm{CO}_{2}$ incubator.

24. Transfer the digested cortices from both Petri dishes (Step 22) into a 50-mL conical tube. Wait for the tissue to settle, and then aspirate and discard the excess liquid with a suction pump.

25. Wash the cells by adding $4.5 \mathrm{~mL}$ of low ovo inhibitor solution from one of the tubes ("Tube 1”) prepared in Step 6.ii. Wait for the cells to settle, then aspirate and discard the excess liquid.

26. Repeat Step 25 four times.

There should be $\sim 4 \mathrm{~mL}$ of low ovo inhibitor solution remaining in Tube 1. This is the low ovo inhibitor solution to which single cells will be added in Step 30.

27. Add $4 \mathrm{~mL}$ of low ovo inhibitor solution from the second tube prepared in Step 6.ii ("Tube 2") to the conical tube of cells for trituration.

28. Use a 5-mL serological pipette to quickly suck up and release the solution of brain + low ovo inhibitor solution (see online Movie 4 at cshprotocols.cshlp.org). As the tissue dissociates, the low ovo inhibitor solution in the tube will become cloudy. Be careful not to introduce bubbles. To minimize the introduction of $\mathrm{CO}_{2}$ into the solution, do not lift the 5-mL pipette out of the solution.

The dissociation buffer (the low ovo inhibitor solution) contains Earle's balanced salts, a bicarbonate-based buffer that requires careful equilibration with $5 \% \mathrm{CO}_{2} / 95 \% \mathrm{O}_{2}$ gas before use and during papain treatment. When the dissociation buffer is exposed to room air during trituration, minimizing surface area and avoiding 
bubbles is essential for maintaining the proper $\mathrm{pH}$ and cell health. When first using this procedure, poor cell health and viability is common, because it is hard to work quickly and efficiently. As the user becomes more practiced, an increase in cell health should be seen.

29. Allow the brain chunks to settle.

30. Collect the single cells (the cloudy solution on top of the brain chunks) with a 1-mL pipette. Add them to the $4 \mathrm{~mL}$ of low ovo inhibitor solution in Tube 1 from Step 26. Avoid transferring the chunks of brain.

31. Repeat the trituration (Steps 27-30) until 95\% of the brain chunks are gone.

Near the end of the procedure, it is normal to have pieces of tissue that cannot be dissociated with gentle pipetting. These pieces of tissue should be discarded, because harsher trituration will results in the cells being ripped apart and poor cell health. (This does not appear to be the case in other procedures, such as oligodendrocyte precursor cell [OPC] preparation, where the cells can tolerate hard pipetting.)

32. Count the cells.

i. Dilute the cells $1: 5$ by combining $20 \mu \mathrm{L}$ of cells with $80 \mu \mathrm{L}$ of $0.02 \%$ BSA/DNase.

ii. Dilute this mixture 1:2 with trypan blue and count the cells using a hemacytometer. Expect approximately 12 million cells per $P 7$ rat brain.

33. Use a 2-mL pipette to remove brain chunks that have settled at bottom of the conical tube with the single cell suspension.

34. Use a $10-\mathrm{mL}$ pipette to carefully layer $12 \mathrm{~mL}$ of high ovo inhibitor solution under the single cell suspension (see online Movie 4 at cshprotocols.cshlp.org).

After this step, there should be a clear layer of liquid beneath a cloudy cell suspension.

35. Centrifuge the cells at $110 \mathrm{rcf}$ for $5 \mathrm{~min}$ in a tabletop centrifuge at room temperature.

The idea here is for the dissociated cells to move down through the high ovo to ensure the complete inhibition of the papain.

Not all of the cells will come down at 110 rcf. Astrocytes at this age tend to be relatively fragile, and viability is decreased if this centrifugation step occurs at a higher speed.

36. Aspirate and discard the supernatant. There should be a visible pellet of cells at the bottom of the conical tube.

37. Resuspend the cell pellet.

i. Add $3 \mathrm{~mL}$ of $0.02 \% \mathrm{BSA} / \mathrm{DNa}$, and gently resuspend the cells by pipetting up and down with a $1-\mathrm{mL}$ pipette.

ii. After the cells are resuspended, add enough $0.02 \% \mathrm{BSA} / \mathrm{DNase}$ to bring the volume up to $9 \mathrm{~mL}$.

38. Make a Nitex filter cone (see online Movie 5 at cshprotocols.cshlp.org), and pre-wet the filter with $1 \mathrm{~mL}$ of $0.02 \% \mathrm{BSA} / \mathrm{DNase}$. Use flamed forceps (spray with ethanol and use a Bunsen flame to sterilize) to hold Nitex filter in place.

39. Filter the resuspended cells through the Nitex mesh to eliminate remaining clumps of cells and chunks of tissue.

i. Filter $1 \mathrm{~mL}$ of resuspended cells at a time.

ii. After the cells have passed through the filter, wash it with $3 \mathrm{~mL}$ of $0.02 \% \mathrm{BSA} / \mathrm{DNase}$.

40. Count the cells.

i. Dilute the cells $1: 5$ by combining $20 \mu \mathrm{L}$ of cells with $80 \mu \mathrm{L}$ of $0.02 \%$ BSA/DNase.

ii. Dilute this mixture 1:2 with trypan blue and count the cells using a hemacytometer.

There should be $\sim 8-10$ million cells per $P 7$ pup at this stage.

41. Allow the cells to recover by incubating them at $37^{\circ} \mathrm{C}$ for $30-45 \mathrm{~min}$ in a $10 \% \mathrm{CO}_{2}$ incubator. This step is critical, because it allows antigens such as ITCB5 to return to the cell surface after papain digestion. 
L.C. Foo

Panning

All panning steps should be done on a flat surface at room temperature.

42. Wash the panning dishes from Step 7 three times with D-PBS (see online Movie 5 at cshprotocols. cshlp.org).

43. Add the cells to the "secondary only" dish. Swirl the dish to distribute the cells evenly. Let the dish sit for $5 \mathrm{~min}$, shake, and then leave to rest for another $5 \mathrm{~min}$ (10 min total).

Cell health is determined by morphology and viability by trypan blue exclusion. We have found that examining cell morphology on the first panning plate is often the best indicator of a gentle, successful procedure. A lack of floating debris indicates good health and dissociation.

44. Transfer the unbound cells (the supernatant) to the "BSL-1" dish. Swirl the dish to distribute the cells evenly. Let the dish sit for $5 \mathrm{~min}$, shake, and then leave to rest for another $5 \mathrm{~min}$ (10 min total).

BSL-1 pulls down a few astrocytes, so it is critical that the cells are not left for longer than $10 \mathrm{~min}$.

45. Transfer the unbound cells to the "CD45" dish. Swirl the dish to distribute the cells evenly. Let the dish sit for $10 \mathrm{~min}$, shake, and then leave to rest for another $10 \mathrm{~min}$ (20 min total).

46. Transfer the unbound cells to one of the "O4" dishes. Swirl the dish to distribute the cells evenly. Let the dish sit for $7.5 \mathrm{~min}$, shake, and then leave to rest for another $7.5 \mathrm{~min}$ (15 min total). Repeat with the second "O4" dish.

47. Transfer the unbound cells to the "ITGB5" dish. Swirl the dish to distribute the cells evenly. Let the dish sit for $20 \mathrm{~min}$, shake, and then leave to rest for another $20 \mathrm{~min}$ (40 min total).

48. Wash the ITGB5 dish approximately eight times with D-PBS.

This dish has the astrocytes bound to it.

49. Add 200 units of trypsin to $8 \mathrm{~mL}$ of equilibrated EBSS. Add this mixture to the washed ITGB5 dish, and incubate the dish in a $37^{\circ} \mathrm{C} / 10 \% \mathrm{CO}_{2}$ incubator for $3 \mathrm{~min}$. Remove the dish from the incubator and tap its side.

i. If cells do not come off easily by tapping the dish, return them to the incubator.

ii. When cells do come off easily, continue to dislodge them by using a $10-\mathrm{mL}$ serological pipette to systematically squirt them with $10 \mathrm{~mL}$ of $30 \%$ FCS (see online Movie 6 at cshprotocols. cshlp.org).

Some contaminating cells (microglia, macrophages) will remain stuck to the plate. These cells are blue under the phase microscope; leave them stuck to the plate to ensure purity of the astrocytes.

Movie 6 depicts pericyte trypsinization, which is done with two 10-cm plates. The concept and procedure is exactly the same for the astrocyte prep, except for the use of only one 15-cm plate and a 10-mL serological pipette to dislodge the cells. Do not leave trypsin at room temperature for an extended period of time. Inactivating trypsin leads to the user shearing the cells off the panning dish rather than lifting them off whole and will thus lead to drastically lower yield.

50. Transfer the dislodged cells to a $50-\mathrm{mL}$ conical tube.

51. Squirt another $10 \mathrm{~mL}$ of $30 \%$ FCS on the dish and then transfer to the conical tube.

52. Dilute the cells by half in trypan blue and count them.

The yield should be $\sim 1$ million cells per $P 7$ rat pup.

53. Add $100 \mu \mathrm{L}$ of $0.4 \%$ DNase per $10 \mathrm{~mL}$ of suspended cells. No incubation is needed at this point.

54. Centrifuge the cells at $170 \mathrm{rcf}$ for $11 \mathrm{~min}$ in a tabletop centrifuge at room temperature, and then aspirate and discard the supernatant.

55. Resuspend the cell pellet in $0.02 \% \mathrm{BSA} / \mathrm{DNase}$ or IP-astrocyte base medium.

56. Preplate cells in $50 \mu \mathrm{L}$ of IP-astrocyte base medium at 2,500 cells/well in a 24 -well plate containing PDL-coated ACLAR plastic coverslips. Incubate the cells in a $37^{\circ} \mathrm{C} / 10 \% \mathrm{CO}_{2}$ incubator for 30 $\min$ to $1 \mathrm{~h}$.

Alternatively, cells can be added directly to preequilibrated HBEGF-containing medium in a 15-cm tissue culture plate. Do not plate too many astrocytes into a dish, or they will starve themselves and overgrow. Typically, we plate 200,000-500,000 cells per 10-cm dish and 1-2 million cells per 15-cm dish; we grow 
them a maximum of $2 w k$ when plated at this density. Astrocytes will divide over time; thus the user needs to determine how many cells to plate based on how long after plating the cells will be used.

57. Carefully add $500 \mu \mathrm{L}$ of IP-astrocyte base medium containing $5 \mathrm{ng} / \mathrm{mL}$ HBEGF to each well of the 24-well plate. Perform a half medium change every $7 \mathrm{~d}$ with fresh $5 \mathrm{ng} / \mathrm{mL}$ HBEGF.

Modifications for Mouse Immunopanning

The procedure for immunopanning for mouse astrocytes is basically the same as that for rat astrocytes, with a few modifications. Instead of using six immunopanning plates, only five are used. No BSL-1 dish is used, but an L1 plate to select for neurons is used before the ITGB5 plate. For the ITGB5 plate, a choice of two secondary antibodies can be used, depending on which primary antibody the user selects.

\section{Mouse Immunopanning Plates}

The following list of plates should be substituted for those described in Step 1 of the rat protocol:

- One "Secondary antibody only" dish: $60 \mu \mathrm{L}$ goat anti-rat IgG $(\mathrm{H}+\mathrm{L})$ (Jackson ImmunoResearch 112-005-167)

- One "CD45" dish: $60 \mu \mathrm{L}$ goat anti-rat $\operatorname{IgG}(\mathrm{H}+\mathrm{L})$

- One "O4" dish: $60 \mu \mathrm{L}$ goat anti-mouse IgM $\mu$-chain specific

- One "L1" dish: $60 \mu \mathrm{L}$ goat anti-mouse $\operatorname{IgG}+\operatorname{IgM}(\mathrm{H}+\mathrm{L})$

- One “ITGB5" dish: $60 \mu$ L Donkey anti-sheep IgG $(\mathrm{H}+\mathrm{L}) \mathrm{ML}^{\star}($ Jackson ImmunoResearch 713-005147) or $60 \mu \mathrm{L}$ Donkey anti-goat IgG $(\mathrm{H}+\mathrm{L})$ minimal cross-reactivity (Jackson ImmunoResearch 705-005-003), depending on which primary antibody the user selects (either sheep or goat ITGB5)

Prepare the mouse panning dishes by coating five 15-cm Petri dishes with $25 \mathrm{~mL}$ of $50 \mathrm{~mm}$ Tris- $\mathrm{HCl}$ $(\mathrm{pH}$ 9.5) per dish and the appropriate secondary antibody solution. Incubate the dishes with the antibody solutions overnight at $4^{\circ} \mathrm{C}$.

The following list of primary antibody solutions should be used to treat the mouse immunopanning plates:

- One "Secondary antibody only" dish: $12 \mathrm{~mL}$ of 0.2\% BSA/DNase

- One "CD45" dish: $20 \mu \mathrm{L}$ rat anti-mouse CD45 in $12 \mathrm{~mL}$ of 0.2\% BSA/DNase

- One "O4" dish: $4 \mathrm{~mL}$ O4 hybridoma supernatant mouse IgM in $8 \mathrm{~mL}$ of $0.2 \%$ BSA/DNase

- One "L1" dish: $10 \mu \mathrm{L}$ of primary antibody (Millipore MAB 5272)

- One "ITGB5" dish (no further coating is needed at this time; anti-ITGB5 antibodies will be added directly to the cell suspension, and then cells will be transferred to this dish)

These solutions substitute for those described in Step 7 of the rat protocol. Allow the coated plates to incubate with primary antibody for at least $2 \mathrm{~h}$ at room temperature before use.

\section{Mouse Immunopanning Sequence}

Dissect the brains and triturate the cells as described in the rat protocol. After washing the panning dishes as in Step 42 of the rat protocol, continue with the following sequence of incubations on a flat surface at room temperature.

1. Add the cells to the "secondary only" dish. Swirl the dish to distribute the cells evenly. Let the dish sit for $10 \mathrm{~min}$, shake, and then leave to rest for another $10 \mathrm{~min}(20 \mathrm{~min}$ total).

2. Transfer the unbound cells (the supernatant) to the "CD45" dish. Swirl the dish to distribute the cells evenly. Let the dish sit for $10 \mathrm{~min}$, shake, and then leave to rest for another $10 \mathrm{~min}$ (20 min total). 
L.C. Foo

3. Transfer the unbound cells to the "O4" dish. Swirl the dish to distribute the cells evenly. Let the dish sit for $10 \mathrm{~min}$, shake, and then leave to rest for another $10 \mathrm{~min}$ (20 min total).

4. Transfer the unbound cells to the "L1" dish. Swirl the dish to distribute the cells evenly. Let the dish sit for $15 \mathrm{~min}$, shake, and then leave to rest for another $15 \mathrm{~min}$ (30 min total).

5. Transfer the unbound cells to a 50-mL conical tube.

6. Add $100 \mu \mathrm{L}$ of $0.2 \mu \mathrm{g} / \mu \mathrm{L}$ ( $20 \mu \mathrm{g}$ total) sheep anti-ITGB5 antibody (R\&D Systems AF3824) to the cell suspension or add $100 \mu \mathrm{L}$ of $0.2 \mu \mathrm{g} / \mu \mathrm{L}(20 \mu \mathrm{g}$ total) goat anti-ITGB5 (Santa Cruz SC5401).

The choice of antibodies depends on which secondary antibody was used to coat the immunopanning plate.

7. Mix the antibody-cell solution on a nutator or shake gently on a rocker for $30 \mathrm{~min}$.

8. Add $100 \mu \mathrm{L}$ of $0.4 \%$ DNase per $10 \mathrm{~mL}$ of suspended cells. No incubation is needed at this point.

9. Centrifuge at $170 \mathrm{rcf}$ in a tabletop centrifuge at room temperature for $10 \mathrm{~min}$, and then aspirate and discard the supernatant.

10. Resuspend the cell pellet in $10 \mathrm{~mL}$ of $0.02 \% \mathrm{BSA} / \mathrm{DNase}$. Transfer the cells to the donkey antisheep secondary dish. Let the dish sit for $15 \mathrm{~min}$, shake, and then leave to rest for another $15 \mathrm{~min}$ (30 min total).

Wash the dish in D-PBS and continue with trypsinization and plating of the cells as described for rats (see Step 48 of the rat protocol).

\section{RELATED INFORMATION}

The purification procedures are based on previously described dissociation (Huettner and Baughman 1986; Segal et al. 1998) and immunopanning purification protocols for other cell types (Meyer-Franke et al. 1995; Barres et al. 1988, 1992).

Enzyme Stock Solution

\begin{tabular}{lrc} 
Reagent & Volume & Final concentration \\
\hline EBSS $(10 \times)$ (Sigma-Aldrich E7510) & $20 \mathrm{~mL}$ & $1 \times$ \\
D $(+)-G l u c o s e(30 \%)$ & $2.4 \mathrm{~mL}$ & $0.46 \%$ \\
$\mathrm{NaHCO}_{3}(1 \mathrm{~m})$ & $5.2 \mathrm{~mL}$ & $26 \mathrm{~mm}$ \\
EDTA $^{2}(50 \mathrm{~mm})$ & $2 \mathrm{~mL}$ & $0.5 \mathrm{~mm}$ \\
ddH $_{2} \mathrm{O}$ & $170.4 \mathrm{~mL}$ &
\end{tabular}

Bring the volume to $200 \mathrm{~mL}$ with $\mathrm{ddH}_{2} \mathrm{O}$ and filter-sterilize through a $0.22-\mu \mathrm{m}$ filter. Store at $4^{\circ} \mathrm{C}$.

High Ovomucoid Stock Solution (10×)

To prepare, add $6 \mathrm{~g}$ of BSA (Sigma-Aldrich A8806) to $150 \mathrm{~mL}$ D-PBS. Add $6 \mathrm{~g}$ of trypsin inhibitor (Worthington LS003086) and mix to dissolve. Add at least $1.5 \mathrm{~mL}$ of $1 \mathrm{~N} \mathrm{NaOH}$ to adjust the $\mathrm{pH}$; continue adding $\mathrm{NaOH}$ as necessary to bring up the $\mathrm{pH}$ to 7.4. Bring the volume to $200 \mathrm{~mL}$ with D-PBS. Filter-sterilize through a $0.22-\mu \mathrm{m}$ filter. Make $1.0-\mathrm{mL}$ aliquots and store at $-20^{\circ} \mathrm{C}$. 
Inhibitor Stock Solution

\begin{tabular}{lrr} 
Reagent & Volume & Final concentration \\
\hline EBSS $(10 \times)($ Sigma-Aldrich E7510) & $50 \mathrm{~mL}$ & $1 \times$ \\
$\mathrm{D}(+)$-glucose $(30 \%)$ & $6 \mathrm{~mL}$ & $0.46 \%$ \\
$\mathrm{NaHCO}_{3}(1 \mathrm{~m})$ & $13 \mathrm{~mL}$ & $26 \mathrm{mM}$ \\
$\mathrm{ddH}_{2} \mathrm{O}$ & $170.4 \mathrm{~mL}$ &
\end{tabular}

Bring the volume to $500 \mathrm{~mL}$ with $\mathrm{ddH}_{2} \mathrm{O}$ and filter-sterilize through a $0.22-\mu \mathrm{m}$ filter. Store at $4^{\circ} \mathrm{C}$.

IP-Astrocyte Base Medium

Reagent

Neurobasal Medium (Gibco/Life

Technologies 21103)

DMEM (Gibco/Life Technologies 11960-044)

Penicillin-streptomycin (Gibco/Life

Technologies 15140-122)

Sodium pyruvate (100 mM; Gibco/Life

Technologies 11360-070)

L-glutamine (200 mm; Gibco/Life

Technologies 25030-081)

SATO supplement, neurobasal-based $(100 \times)<\mathrm{R}>$

NAC stock $(5 \mathrm{mg} / \mathrm{mL})<\mathrm{R}>$
Final concentration

\section{$50 \%$}

$50 \%$

$100 \mathrm{U} / \mathrm{mL}$ (penicillin) 100

$\mu \mathrm{g} / \mathrm{mL}$ (streptomycin)

$1 \mathrm{~mm}$

$292 \mu \mathrm{g} / \mathrm{mL}$

$1 \times$

$5 \mu \mathrm{g} / \mathrm{mL}$

Filter-sterilize through a $0.22-\mu \mathrm{m}$ filter. Store at $4^{\circ} \mathrm{C}$ in the dark.

Low Ovomucoid Stock Solution (10×)

To prepare, add $3 \mathrm{~g}$ of BSA (Sigma-Aldrich A8806) to $150 \mathrm{~mL}$ D-PBS. Mix well. Add $3 \mathrm{~g}$ of trypsin inhibitor (Worthington LS003086) and mix to dissolve. Add $\sim 1 \mathrm{~mL}$ of $1 \mathrm{~N} \mathrm{NaOH}$ to adjust the $\mathrm{pH}$ to 7.4. Bring the volume to $200 \mathrm{~mL}$ with D-PBS. Filter-sterilize through a 0.22 $\mu \mathrm{m}$ filter. Make $1.0-\mathrm{mL}$ aliquots and store at $-20^{\circ} \mathrm{C}$.

\section{NAC Stock $(5 \mathrm{mg} / \mathrm{mL})$}

To prepare, dissolve $50 \mathrm{mg}$ of $\mathrm{N}$-acetyl-L-cysteine (NAC) powder (Sigma-Aldrich A8199) in $10 \mathrm{~mL}$ of Neurobasal Medium (Gibco/Life Technologies 21103). (The solution will be yellowish.) Filter through a $0.22-\mu \mathrm{m}$ filter. Prepare 20 - and $80-\mu \mathrm{L}$ aliquots and store them frozen at $-20^{\circ} \mathrm{C}$.

\section{SATO Supplement, NB-based (100×)}

1. Prepare the following stock solutions (these should be made fresh; do not reuse).

- Combine $2.5 \mathrm{mg}$ of progesterone (Sigma-Aldrich P8783) and $100 \mu \mathrm{L}$ of ethanol to make a progesterone stock solution.

- Combine $4.0 \mathrm{mg}$ of sodium selenite (Sigma-Aldrich S5261), $10 \mu \mathrm{L}$ of $1 \mathrm{~N} \mathrm{NaOH}$, and $10 \mathrm{~mL}$ of Neurobasal (NB, Gibco 21103-049) to make a sodium selenite stock solution.

2. Add the following to $80 \mathrm{~mL}$ of Neurobasal medium: 
L.C. Foo

Reagent

BSA (Sigma-Aldrich A4161)

Transferrin (Sigma-Aldrich

T1147)

Putrescine dihydrochloride

(Sigma-Aldrich P5780)

Progesterone stock solution

Sodium selenite stock solution
Quantity Final concentration in medium $(1 \times)$

$\begin{array}{ll}800 \mathrm{mg} & 100 \mu \mathrm{g} / \mathrm{mL} \\ 800 \mathrm{mg} & 100 \mu \mathrm{g} / \mathrm{mL}\end{array}$

$128 \mathrm{mg}$

$16 \mu \mathrm{g} / \mathrm{mL}$

$20 \mu \mathrm{L}$

$800 \mu \mathrm{L}$
$60 \mathrm{ng} / \mathrm{mL}(0.2 \mu \mathrm{M})$

$40 \mathrm{ng} / \mathrm{mL}$

3. Mix well, and filter-sterilize through a prerinsed $0.22-\mu \mathrm{m}$ filter. Make $200-\mu \mathrm{L}$ or $800-\mu \mathrm{L}$ aliquots, and store at $-20^{\circ} \mathrm{C}$.

\section{ACKNOWLEDGMENTS}

We thank Dr. Jim Huettner for helpful comments on the adaptation of his neuronal dissociation procedure to allow for glial purification.

\section{REFERENCES}

Bansal R, Pfeiffer SE. 1989. Reversible inhibition of oligodendrocyte progenitor differentiation by a monoclonal antibody against surface galactolipids. Proc Natl Acad Sci 86: 6181-6185.

of Barres BA, Silverstein BE, Corey DP, Chun LL. 1988. Immunological, morphological, and electrophysiological variation among retinal ganglion cells purified by panning. Neuron 1: 791-803.

Barres B, Hart I, Coles H, Burne J, Voyvodic J, Richardson W, Raff M. 1992. Cell death and control of cell survival in the oligodendrocyte lineage. Cell 70: 31-46.
Huettner JE, Baughman RW. 1986. Primary culture of identified neurons from the visual cortex of postnatal rats. J Neurosci 6: 3044 3060 .

Meyer-Franke A, Kaplan M, Pfrieger F, Barres B. 1995. Characterization of the signaling interactions that promote the survival and growth of developing retinal ganglion cells in culture. Neuron 15: 805-819.

Segal M, Baughman R, Jones K. 1998. Stanford WebLogin (Culturing nerve cells). 


\section{Purification of Rat and Mouse Astrocytes by Immunopanning}

Lynette C. Foo

Cold Spring Harb Protoc; doi: 10.1101/pdb.prot074211

\begin{tabular}{|c|c|}
\hline $\begin{array}{r}\text { Email Alerting } \\
\text { Service }\end{array}$ & Receive free email alerts when new articles cite this article - click here. \\
\hline $\begin{array}{l}\text { Subject } \\
\text { Categories }\end{array}$ & $\begin{array}{l}\text { Browse articles on similar topics from Cold Spring Harbor Protocols. } \\
\text { Immunoaffinity Purification ( } 49 \text { articles) } \\
\text { Immunoseparation ( } 31 \text { articles) } \\
\text { Mouse ( } 437 \text { articles) } \\
\text { Neural Cell Culture (57 articles) } \\
\text { Neuroscience, general ( } 357 \text { articles) } \\
\text { Other Laboratory Organisms ( } 68 \text { articles) }\end{array}$ \\
\hline
\end{tabular}

